\title{
Abandonment of cultural landscapes: butterfly communities track the advance of forest over grasslands
}

\author{
Amparo Mora ${ }^{1,2}$ (D) Andrew Wilby ${ }^{1}$ (D) $\cdot$ Rosa Menéndez $^{1}$ (D)
}

Received: 23 June 2021 / Accepted: 1 December 2021 / Published online: 14 December 2021

(c) The Author(s) 2021

\begin{abstract}
Rural landscapes in Europe have suffered considerable land-use change in the last 50 years, with agricultural intensification in western regions and land abandonment in eastern and southern regions. The negative impacts of agricultural intensification on butterflies and other insects in western Europe have been well studied. However, less is known about the impacts of abandonment on mountain and humid areas of eastern and southern Europe, where landscapes have remained more natural. We sampled butterfly communities in the Picos de Europa National Park (Spain), a region which is undergoing a process of rural abandonment. 19 hay meadows with different periods of abandonment were studied (long-term 18 years or midterm abandoned, 3-7 years) and compared to meadows continuously managed in a traditional way. We examined how local meadow characteristics and landscape variables affected butterfly community response to abandonment. Butterfly communities were affected by abandonment, with an overall increase in the density of individuals in the long term. Community composition appears to undergo major change over time, with a species turnover of around $50 \%$ in the first few years of abandonment, rising to around $70 \%$ after 18 years of abandonment. There was a tendency for species with higher preference for closed habitats to increase their densities as time since abandonment proceeded. Landscape variables had a major impact on butterfly communities, stronger than the effect of meadow management. Community preference for closed habitats was associated with higher forest cover in the surroundings of the meadows, but heterogeneous landscapes (in their composition or configuration) mitigated this effect.

Implications for insect conservation Our findings suggest that we should ensure that communities have time to react to the diverse stressors imposed by global change. Facilitating survival to all kinds of functional and taxonomic groups implies promoting landscape heterogeneity and connectivity.
\end{abstract}

Keywords Abandonment · Biodiversity indicators $\cdot$ Butterflies $\cdot$ Meadow management $\cdot$ Open/closed habitat $\cdot$ Species traits

\section{Introduction}

Biodiversity loss caused by human actions has overcome a critical threshold. Up to $75 \%$ of the terrestrial environment has been "severely altered", with land use change among the

Amparo Mora

amora@pnpeu.es

Andrew Wilby

a.wilby@lancaster.ac.uk

Rosa Menéndez

r.menendez@lancaster.ac.uk

1 Lancaster Environment Centre, Lancaster University, Lancaster, UK

2 Picos de Europa National Park, Asturias, Spain most important direct drivers of habitat loss and degradation (Brondizio et al. 2019). Rural landscapes in Europe have suffered considerable land-use change in the last 50 years, with agricultural intensification in western regions and land abandonment in eastern and southern regions (van Swaay et al. 2016). The negative impacts of agricultural intensification on butterflies in western Europe have been well studied and landscape matrix composition around cultivated land has been shown to be crucial on butterfly community dynamics (Perović et al. 2015; Seibold et al. 2019; Gámez-Virués et al. 2015; Dainese et al. 2017; Öckinger et al. 2012). However, less is known about the impacts on grassland butterflies in mountain and humid areas of eastern and southern Europe, where landscapes have remained more natural and agricultural abandonment rather than intensification has taken place 
(but see Marini et al. 2009; Slancarova et al. 2016; Ubach et al. 2020; Colom et al. 2021).

The butterfly community in any given grassland will be the result of both local and landscape-level filters (Perović et al. 2015). Among the various negative local impacts of grasslands abandonment, decreases in plant diversity are particularly critical as several studies have shown that declines in producers reduces diversity at higher trophic levels (Poyry et al. 2009; Uchida and Ushimaru 2014; Dainese et al. 2017). A reduction in plant diversity within the grassland could affect nectar resources (Krauss et al. 2003) and potentially hostplant availability, which have been shown to negatively affect butterfly diversity (Skórka et al. 2007; Marini et al. 2009).

On the other hand, landscape heterogeneity can moderate the effects of local grassland management and influence species persistence, by supporting a larger species pool, providing a diversity of patches with different disturbance dynamics and encouraging spillover of organisms between complementary resources (van Halder et al. 2011; Tscharntke et al. 2012; Janisová et al. 2014; Dantas de Miranda et al. 2019). Therefore, understanding how landscape structure (i.e. composition:diversity of habitat types;- and configuration: number, size and arrangement of habitat patches) moderates the response of species and communities to changes in habitat management, is critical to comprehending their dynamics (Tscharnke et al. 2012). Movements of species between landscape elements may ensure community resilience, the capacity to reorganise after disturbance in changing environments (Tscharntke et al. 2007).

Agricultural intensification and land abandonment are changes that act as ecological filters on butterfly communities affecting both the functional and taxonomic composition of communities (Gámez-Virués et al. 2015; Herrando et al. 2016). Recent research has shown that focusing on traits at the community level provides ecologically meaningful insights into the landscape-level processes affecting community assembly, which would not be detectable by focusing on single species or taxonomic diversity alone (Öckinger et al. 2010; Ubach et al. 2020). Community trait indices weighted by species abundances have proved very powerful tools in detecting community responses to environmental change (Julliard et al. 2006; Devictor et al. 2012; Gagic et al. 2015; Moretti et al. 2017). For example, species with limited dispersal ability, diet specialisation and low fecundity are selected against in intensively managed agroecosystems (McKenney and Lockwood 1999; Perović et al. 2015), being at higher risk of extinction as a result.

In the European context, responses to intensification are relatively well documented, but the impacts of abandonment are less clear, particularly in landscapes harbouring higher diversity of both habitats and species. The abandonment of traditional land is leading to a loss of habitats dominated by sparse vegetation, thereby giving rise to a successional progression towards forest habitats (Poschlod et al. 2005) and consequent changes in butterfly species composition. Balmer and Erhardt (2000) detected a peak on butterfly species richness 10 years after abandonment of extensively grazed grasslands in the Jura Mountains (Switzerland), with a subsequent decline at around 20-30 years of abandonment, when the grassland became young forest. In the southern Balkans, vegetation encroachment of formerly open habitats has been shown to decrease the representation of Mediterranean endemic butterfly species relative to northern European species (Slancarova et al. 2016).

In Spain, between 1962 and 2019, 4 million hectares of cultivated land were abandoned (around $8 \%$ of total national surface), increasing forest cover, which now accounts for $55 \%$ of total national surface, of which around $80 \%$ is not managed (Greenpeace Spain 2020). The consequences of these huge land use changes on butterflies have been explored only in the northeast Mediterranean region (Stefanescu et al. 2009; Herrando et al. 2016; Ubach et al. 2020). These studies showed that grassland abandonment had immediate strong effects on butterflies, including the substitution of grassland specialist by habitat-generalist butterflies (Stefanescu et al. 2009). They also demonstrated that for both birds and butterflies, open-habitat species showed the most marked declines, whilst forest species increased moderately, a pattern in line with the changes occurring in forest cover in the surrounding landscape (Herrando et al. 2016; Ubach et al. 2020).

In the more humid Atlantic parts of Spain, the Cantabrian Mountains, recent studies have shown an increase of $16 \%$ of forest cover between 1990 and 2000 (García-Llamas et al. 2019). Parallel to this regional pattern, the area of traditional hay meadows decreased by $70 \%$ between 1956 and 2017 in the Picos de Europa National Park, doubling the rate in the last decade (García et al. 2018). The consequences of this land transformation on biodiversity are still largely unexplored. This is particularly worrying as Picos de Europa is a hotspot of butterfly diversity not only in the Iberian Peninsula, but in the broader European context (van Swaay and Warren 2006; Romo et al. 2007). There are 137 butterfly species in the National Park, representing $60.6 \%$ of the Iberian species (García-Barros et al. 2013), including several legally protected species at European level (Parnassius apollo, Euphydryas aurinia, Lopinga achine and Phengaris nausithous) and some Iberian endemisms (Erebia palarica, Aricia morronensis and Agriades pyrenaicus).

Here, our aim was to assess how traditional hay meadow abandonment is affecting butterfly communities in the Picos de Europa National Park and how local meadow characteristics and landscape context modulate these responses.

We hypothesize that: 
Fig. 1 Study site and sampled meadows at Picos de Europa National Park (northern Spain)

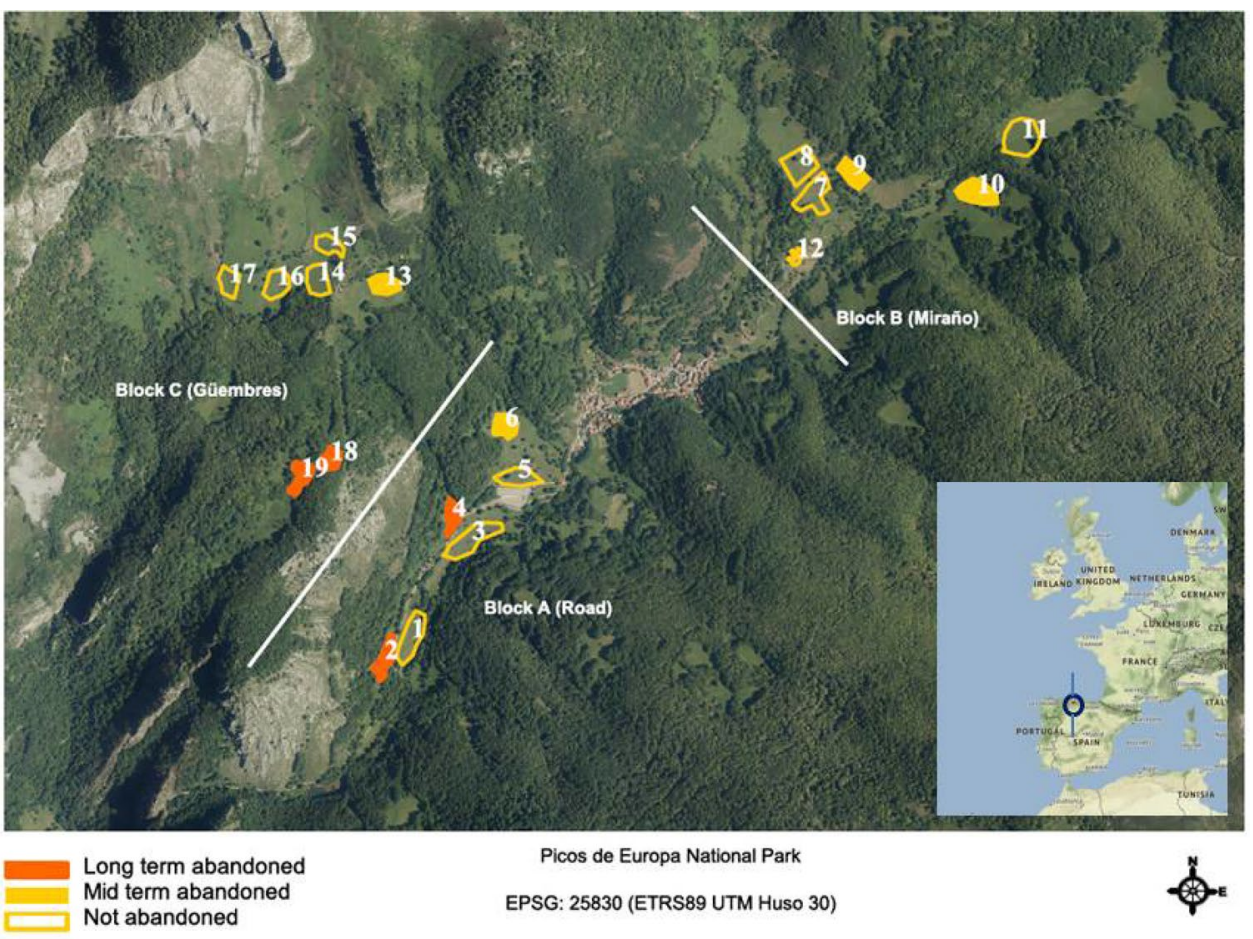

(1) Traditionally managed meadows harbour higher species richness, diversity and abundance of butterflies than abandoned grasslands.

(2) Abandonment affects butterfly communities through effects on vegetation characteristics within the meadow, such as increase in sward height and vegetation cover and reduction in plant richness and diversity.

(3) Landscape heterogeneity and the extent of open versus closed habitats in the landscape (grassland versus woodland), influences the response of butterfly communities to abandonment.

\section{Methods}

\section{Study area}

The study was carried out in Soto de Sajambre (Oseja de Sajambre municipality), on the southern side of Picos de

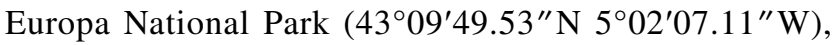
in the north of Spain (Fig. 1). The study area comprised approximately $3 \times 2 \mathrm{~km}^{2}$, with an elevation range from 884 to $1137 \mathrm{~m}$ (average 1023.64 \pm 89.14 ). Soto de Sajambre has a hyperhumid climate, with an average annual temperature of $9.3^{\circ} \mathrm{C}$ and an annual rainfall of $1783 \mathrm{~mm}$ (Rivas Martínez et al. 1984). Nevertheless, it receives Mediterranean influences from the south (Leon-Castilla plateau) and from the east (Ebro Depression), which is reflected in the flora of the region, containing $13.18 \%$ of Mediterranean plant species (Alonso Felpete et al., 2011).

Nineteen hay meadows were selected, with size ranging between 0.29 and 0.81 ha (average 0.47 ha \pm 0.15 ). The meadows were located in three areas/blocks (see Fig. 1), each one containing continuously managed (for more than 50 years) and abandoned meadows (time since management varied between 3 and 18 years). Abandoned meadows were classified into two categories: mid-term abandoned (3-7 years) and long-term abandoned (18 years) (see Table S1 for details on each meadow). All meadows in blocks A and B were grazed from September to April by approximately 110 cows and 25 mares that moved freely around the village, with an approximate density of 0.18 cows/ha and 0.041 mares/ha. Meadows in block $\mathrm{C}$ were not grazed by domestic animals, being the uppermost and furthest location from the village. Wild herbivores (red and roe deer and wild boar) also foraged occasionally in small numbers on the meadows. Managed meadows are mown once a year, in July or August depending on their altitude. While the meadows were originally fertilised with manure, this practice has ceased to prevent wild boar damage. Other traditional management practices, such as pruning of trees in the hedgerows to prevent shadowing of the meadow and maintenance of water drainage channels, are also no longer used. Information about abandonment time (i.e. years without mowing) and use for grazing by cattle and wild herbivores was obtained from Park rangers and farmers. 


\section{Butterfly surveys and butterfly traits}

In each selected meadow, a zig-zag transect was walked identifying and counting any butterfly seen $2.5 \mathrm{~m}$ either side and $5 \mathrm{~m}$ ahead following the standardized methods proposed by Pollard and Yates (1993). Minimum conditions for sampling were temperature above $17^{\circ} \mathrm{C}$, wind below 3 (Beaufort scale) and no rain. Transect length was $500 \mathrm{~m}$, transect duration around $20 \mathrm{~min}$ and they were walked between 11:00 and 16:00. Transects were repeated three times during the season: mid-May, mid-June and mid-July in 2019, in order to register the maximum diversity and abundance of butterflies in the area before meadows were mown, and all surveys were done by the same person. Some Pyrgus spp and Melitaea spp were not possible to identify to species level, as most species require dissecting their genitalia for correct identification, and were not included in the analysis.

Species traits related to habitat and trophic specialisation and dispersal ability were compiled from the scientific literature for each butterfly species recorded (Table S2). We used the TAO index of species preferences for open/closed habitats developed by Ubach et al. (2020), which is based on the Catalan Butterfly Monitoring Scheme data (1994-2017, 93 sites) (see details in www.catalanbms.org). Species showed great consistency in their preferences for open or closed habitats regardless of the climatic conditions in the different biogeographic regions analysed by Ubach et al. (2020), so we believe that this index is valid for our study area, and more appropriate than other indices used to described butterfly habitat selection in western Europe. The TAO index takes a " +1 " value when the butterfly species prefers completely open habitats and takes a " -1 " value when the butterfly species prefers completely closed habitats.

We developed community indices based on species traits (preference for open/closed habitats, habitat specialisation, trophic specialisation and dispersal ability). These indices were calculated for each meadow, as the average of species individual indices weighted by species abundances. Therefore, changes in these indices mostly result from variations in the dominant species occurring locally.

We followed Julliard et al. (2006) and Devictor et al. (2012) to develop a community index of preference for open/closed habitats (CTAO) for each meadow (Table S3), by multiplying each species index by the square root of its abundance and then averaging across all species. Habitat specialisation, trophic specialisation and dispersal ability information for each species were taken from Stefanescu et al. (2010) and the same procedure as described above was used to build the community indices (Table S3).

\section{Vegetation surveys}

Within each meadow, three $1 \mathrm{~m}^{2}$ quadrats were placed along the butterfly transect route. In every quadrat percentage cover of flowering plants, vegetation height and soil humidity were recorded. Soil humidity was measured with a ThetaProbe sensor (Delta-T Devices Ltd.), which measures volumetric soil moisture content by responding to changes in the dielectric constant of the soil. Soil samples were taken from several of the meadows for calibration of soil humidity measures in the laboratory. Surveys were repeated three times during the season: mid-May, mid-June and mid-July in 2019, paired to butterfly sampling periods. All plant surveys were done by the same person.

\section{Landscape metrics}

A map of the Picos de Europa National Park at 1:10.000 scale containing vegetation cover features was used to extract landscape variables (Alonso et al. 2013). Vegetation cover was classified on 16 specific categories and in four general categories (grasslands, forest, scrub and other). For each meadow, we drew a circular landscape of $200 \mathrm{~m}$ radius and extracted vegetation data from the vegetation map (Fig. S1). We did not examine larger radii because study sites were close in proximity to each other (area was ca. $3 \times 2$ $\mathrm{km}^{2}$ ).

The Shannon diversity index of vegetation types (those defined as specific categories) was used to represent compositional landscape heterogeneity. The average patch size inside the circular landscapes of $200 \mathrm{~m}$ radius was used to represent configurational landscape heterogeneity (Perovic et al. 2015; Gámez-Virués 2015). For each landscape, the proportion of the three general vegetation categories (grassland, forest and scrub) was calculated. Landscape metrics were calculated using gvSIG2.5.1 (http://www.gvsig.com).

\section{Data analysis}

The response of butterfly community attributes to time since abandonment and to both meadow characteristics (plant species richness and diversity, vegetation high and cover, soil humidity, distance to water, elevation and slope) and landscape variables (compositional and configurational landscape heterogeneity; and forest, grasslands and scrub cover) were analysed using generalized linear mixed-effect models (GLMM). The response variables were: species richness (rarefied), Shannon diversity index $\left(\mathrm{H}^{\prime}\right)$, butterfly density (as number of individuals recorded per $100 \mathrm{~m}$ transect), and functional community attributes, represented by the community index of each trait. All response variables followed a Gaussian error structure. The block was assigned as a random effect. The statistical significance of the fixed factors in 
each GLMM was tested with analysis of variance (ANOVA), comparing the fitted model containing the fixed factor with the null model containing only the random term. The block was assigned as a random effect. GLMMs were also used to test the effect of time since abandonment on plant richness, plant diversity (Shannon index) and plant cover (as average proportion in a $1 \mathrm{~m}^{2}$ quadrat). Plant richness followed a Poisson distribution, plant diversity a Gaussian distribution and plant cover a negative binomial error structure. The fixed effect was time since abandonment (3 levels) and block was included as a random effect. The statistical significance of the fixed factor was assessed as described above for the butterfly analysis. GLMMs analyses were performed with "Ime4" package in R (Bates et al. 2015).

To assess whether the community composition of butterflies differed among time since abandonment categories, we used non-metric multidimensional scaling (NMDS) ordinance analysis based on Bray-Curtis pairwise distance. We tested which meadow characteristics (plant richness, diversity and cover, vegetation height, distance to water, soil humidity, altitude and slope) were having an influence on butterfly communities. For this, we used functions "metaMDS" and "envfit" from "vegan" package (Oksanen et al. 2019).

We performed Indicator Species Analysis to test if there were butterfly species which were indicators of different abandonment categories (long-term or mid-term abandoned or unabandoned meadows). We used the "multipatt" function from "indicspecies" package in R (De Cáceres and Legendre 2009). Function "multipatt" allows determination of lists of species that are associated to particular group of sites. It uses the approach by Dufrêne and Legendre (1997), who defined an Indicator Value (IndVal) index to measure the association between a species and a site group. The method calculates the index and then looks for the group corresponding to the highest association value. Finally, the statistical significance of this relationship was tested using a permutation test. Multipatt uses the IndVal index as test statistic (De Cáceres 2020).

All statistical analyses were performed using the software RStudio for Statistical Computing (version 1.2.5019; RStudio Development Team 2019).

\section{Results}

In total, 741 individuals belonging to 56 butterfly species were recorded across the 19 surveyed meadows (Table S5). A species accumulation curve showed this to be a comprehensive representation of the butterfly community in the study area (Figure S3). The species recorded represent $41 \%$ of species present in the Picos de Europa Nation Park and $25 \%$ of Iberian Peninsula and Balearic Islands butterfly fauna. The most abundant species were Maniola jurtina, Melanargia galathea and Colias croceus representing $58 \%$ of all recorded individuals. Several rare species were recorded at low density, including Argynnis adippe, Boloria euphrosyne, Carterocephalus palaemon, Hamearis lucina and Lycaena hippothoe.

\section{Effects of time since abandonment on butterfly communities}

There was no significant effect of time since abandonment on butterfly species richness or diversity $\left(\chi^{2}=1.736\right.$, $\mathrm{p}=0.419$ and $\chi^{2}=1.978, \mathrm{p}=0.371$ respectively; Fig. 2A, B). However, density of butterflies was significantly higher in long term abandoned meadows than in mid-term abandoned or unabandoned meadows $\left(\chi^{2}=8.92, p=0.011\right.$; Fig. $\left.2 \mathrm{C}\right)$.

Butterfly community preference for open/closed habitats (CTAO index) tended to decrease with time since abandonment (Fig. 2D) but the differences were only marginally significant $\left(\chi^{2}=4.792, p=0.091\right)$. Butterfly communities did not differ in trophic specialisation index $\left(\chi^{2}=0.513\right.$, $\mathrm{p}=0.773)$, habitat specialisation index $\left(\chi^{2}=0.953\right.$, $\mathrm{p}=0.620)$ or dispersal ability index $\left(\chi^{2}=0.855, \mathrm{p}=0.651\right)$ among long-term, mid-term or unabandoned meadows.

Long-term abandoned meadows held butterfly communities that differed in composition from mid-term abandoned or unabandoned meadows (Fig. 3). These last two categories were not completely segregated. Six butterfly species (Coenonympha arcania, Thymelicus sylvestris, Leptidea sinapis, Melanargia galathea, Aphantopus hyperanthus and Lycaena virgaureae) came out as significant indicators of long-term abandoned meadows and two species (Lysandra bellargus and Polyommatus icarus) as indicators of unabandoned meadows (Table S4).

Species turnover in butterfly communities as time of abandonment proceeded was high, with a $53.1 \%$ of species change (23 lost, 3 gained) in the first 3-7 years of abandonment; and $70 \%$ of species change ( 7 lost, 8 recovered, 4 gained) after 18 years of abandonment (see Table S5 for the list of species present in each abandonment category).

\section{Local context influence on butterfly community response to abandonment}

Vascular plant species richness peaked at 3-7 years after abandonment and then declined below the initial values in unabandoned meadows $\left(\chi^{2}=10.74, p=0.001\right.$; Fig. 4A). Vascular plant diversity was also higher after 3-7 years of abandonment and then decreased in the long term, remaining at higher values 18 years after abandonment than in unabandoned meadows $\left(\chi^{2}=8.150, p=0.016\right.$; Fig. 4B). Vascular plant cover $\left(\chi^{2}=0.874, p=0.645\right.$; Fig. 4 C $)$ and 

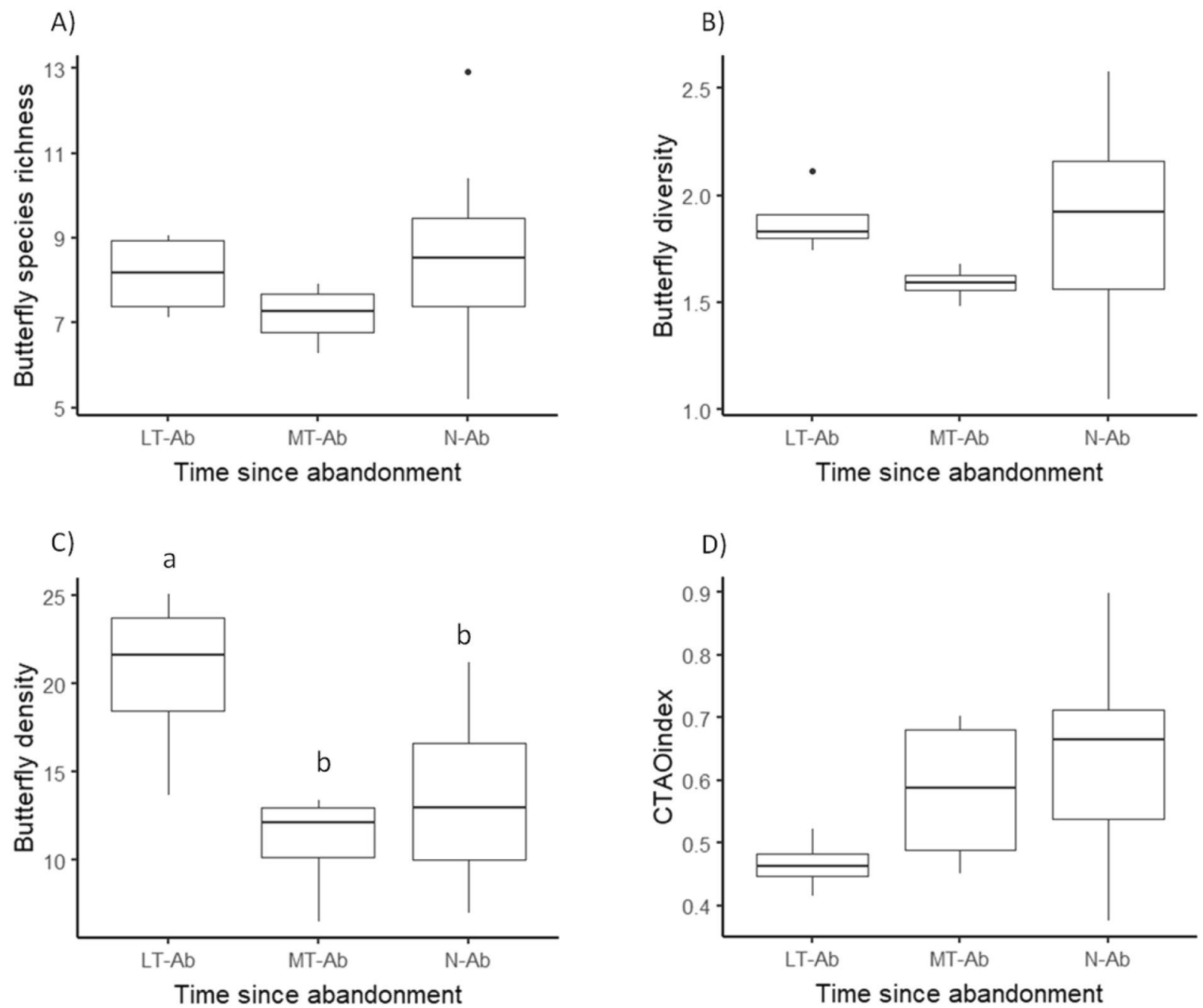

Fig. 2 Butterfly species richness (measured as rarefied species richness) (A), diversity (measured as Shannon index) (B), density (C) and community index of preference for open/closed habitats (CTAO index, $-1=$ closed habitats, $+1=$ open habitats) $(\mathbf{D})$ in meadows of

vegetation height $\left(\chi^{2}=2.872, p=0.237\right.$; Fig. 4D) did not change with time since abandonment.

However, of the local environmental variables analysed (plant species richness, diversity and cover, vegetation height, distance to running water, soil humidity, altitude and orientation, see Table S6), only vegetation height had a marginally significant positive effect on butterfly species richness $\left(\chi^{2}=2.825, \mathrm{p}=0.092\right)$ and diversity $\left(\chi^{2}=2.945, p=0.086\right)$. Butterfly community composition was also not significantly explained by any of the local variables measured within the meadow, except for time since abandonment $\left(R^{2}=0.274, p=0.034\right.$, see Table $S 7$ for other variables).

different years of abandonment, categorized as unabandoned (N-Ab), mid-term abandoned (MT-Ab) and long-term abandoned (LT-Ab). Different letters above the boxplots indicate significant differences between abandonment categories at $\mathrm{p}<0.05$ (Post-Hoc Tukey test)

\section{Landscape context influence on butterfly community response to abandonment}

Grassland and forest cover were strongly negatively correlated $(\mathrm{R}=-0.82, \mathrm{p}<0.001)$ (see Table S8). Similarly, scrub and forest cover were negatively correlated, but not so strongly $(\mathrm{R}=-0.58, \mathrm{p}<0.05)$. The advance of forests over grasslands because of abandonment was associated with a loss of landscape configurational heterogeneity (correlation between average patch size and grassland cover, $\mathrm{R}=0.54, \mathrm{p}<0.05)$. Landscape habitat diversity increased parallel to scrub cover $(R=0.50, p<0.05)$.

No landscape effects were detected on butterfly species richness, diversity or density, on community index for 


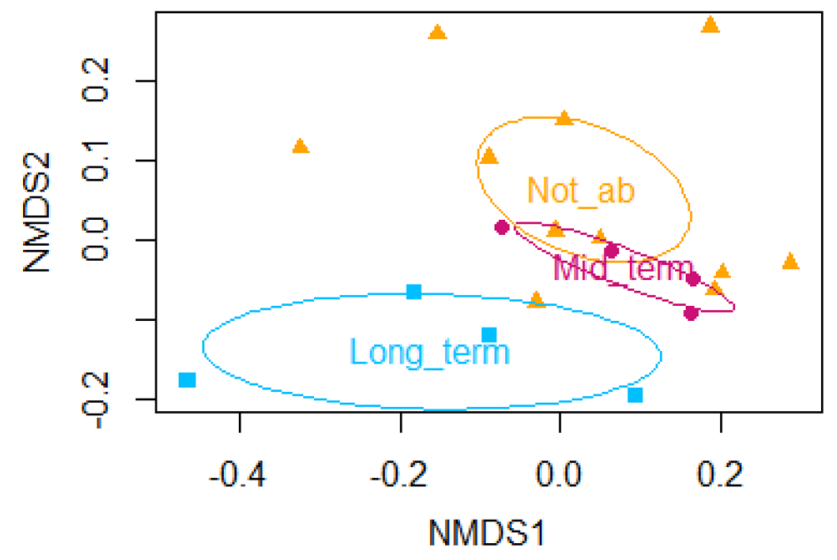

Fig. 3 NMDS analysis for butterfly communities (stress $=0.09$ ) grouped by time since abandonment categories: unabandoned $(\mathrm{N}-\mathrm{Ab})$, mid-term abandoned (MT-Ab) and long term abandoned (LT-Ab). Ellipses show the 95\% confidence intervals for the group centroids

trophic specialisation, habitat specialisation or dispersal ability (see Table S9). The butterfly community preference index for open/closed habitats (CTAO index) increased when the landscape around the meadow was more heterogeneous (Fig. 5A, B), because of a higher habitat diversity (compositional heterogeneity, $\chi^{2}=5.872, p=0.015$ ) or because of a smaller average habitat patch size (which means a higher configurational heterogeneity, $\left.\chi^{2}=9.047, p=0.002\right)$. The result remained significant for configurational heterogeneity $\left(\chi^{2}=6.823, p=0.009\right.$, Fig. S2) after removing two outliers (meadows 23 and 24) but not for compositional heterogeneity $\left(\chi^{2}=0.051 \mathrm{p}=0.819\right.$, Fig. S2).

The CTAO index also increased when there was a higher proportion of grassland and scrub in the landscape around the meadows $\left(\chi^{2}=7.443, \mathrm{p}=0.006\right.$ and $\chi^{2}=6.083$, $\mathrm{p}=0.013$, respectively) but decreased when the proportion of forest cover was higher around the meadows $\left(\chi^{2}=10.74\right.$, $\mathrm{p}=0.001)($ Fig. 5C-E).

\section{Discussion}

The aim of this study was to identify how abandonment of traditional hay meadows is affecting butterfly communities and how landscape context modulates these responses. The result shown that butterfly communities were affected by abandonment, with an overall increase in density of individuals after 18 years of abandonment. Community composition went through major changes with a species turnover of around $50 \%$ in the first years of abandonment and around $70 \%$ after 18 years of abandonment. There was a tendency of species with preference for closed habitats to increase in density as time since abandonment proceeded. Landscape variables had a larger impact on butterfly communities than local management, with butterfly community preference index for open habitats being lower in meadows surrounded by high forest cover. However, heterogeneous landscapes (in their composition or configuration) mitigated this effect, resulting in communities having a higher value for the index independent of the habitat cover surrounding the meadow.

We found that vascular plant communities changed quickly, with significant differences in both species richness and diversity with time since abandonment, peaking at 3-7 years after abandonment but decreasing in the long term to below the initial values. However, these changes in the plant community within the meadow did not have a significant effect on the butterfly communities. Some studies have demonstrated that declines in producers reduces diversity at higher trophic levels (Pöyry et al. 2009; Uchida and Ushimaru 2016; Dainese et al. 2017). Moreover, higher plant diversity has been shown to correlate well with nectar resource availability (Krauss et al. 2003), with potential effects on butterfly diversity (Skórka et al. 2007; Marini et al. 2009). However, we did not observe this pattern at the temporal and spatial scales studied.

We argue that previous studies were conducted in landscape matrices where remaining grasslands were a small percentage of the total land cover (2-3\% as maximum). Such landscapes were very likely below extinction thresholds for species that exhibited long-term negative population trends (Pöyry et al. 2009). In our study, with a remaining mean grassland cover of around $40 \%$, mobility of butterflies across the landscape, among different successional patches of different age, could be buffering the negative effect of plant diversity loss in abandoned meadows. Our results suggest that a matrix with enough suitable habitat remaining, embedded in a more heterogeneous landscape, can slow down the negative effects of plant diversity loss on butterfly communities (Marini et al. 2009).

Total butterfly density in the meadows increased with abandonment in the long term, this may be due to the absence of mortality caused by annual mowing. Mowing can be detrimental in the long term on butterfly populations, particularly for species with adults flying in late summer, low dispersal ability or very strict resource requirements (Johst et al. 2006; Konvicka et al. 2008). It has been shown that mowing leads to high insect mortality, with percentages ranging from 20 to $69 \%$ depending on the mowing technique (Humbert et al. 2010, 2012). Dover et al. (2010) found a significant decline in the abundance of typical grassland butterflies, such as the satyrids, in fields harvested for hay but no significant declines for other butterfly groups; which suggests that mortality rather local migration (due to decline in nectar resource) was likely responsible for the rapid decline in satyrids. Bruppacher et al. (2016) showed that simple modifications of 

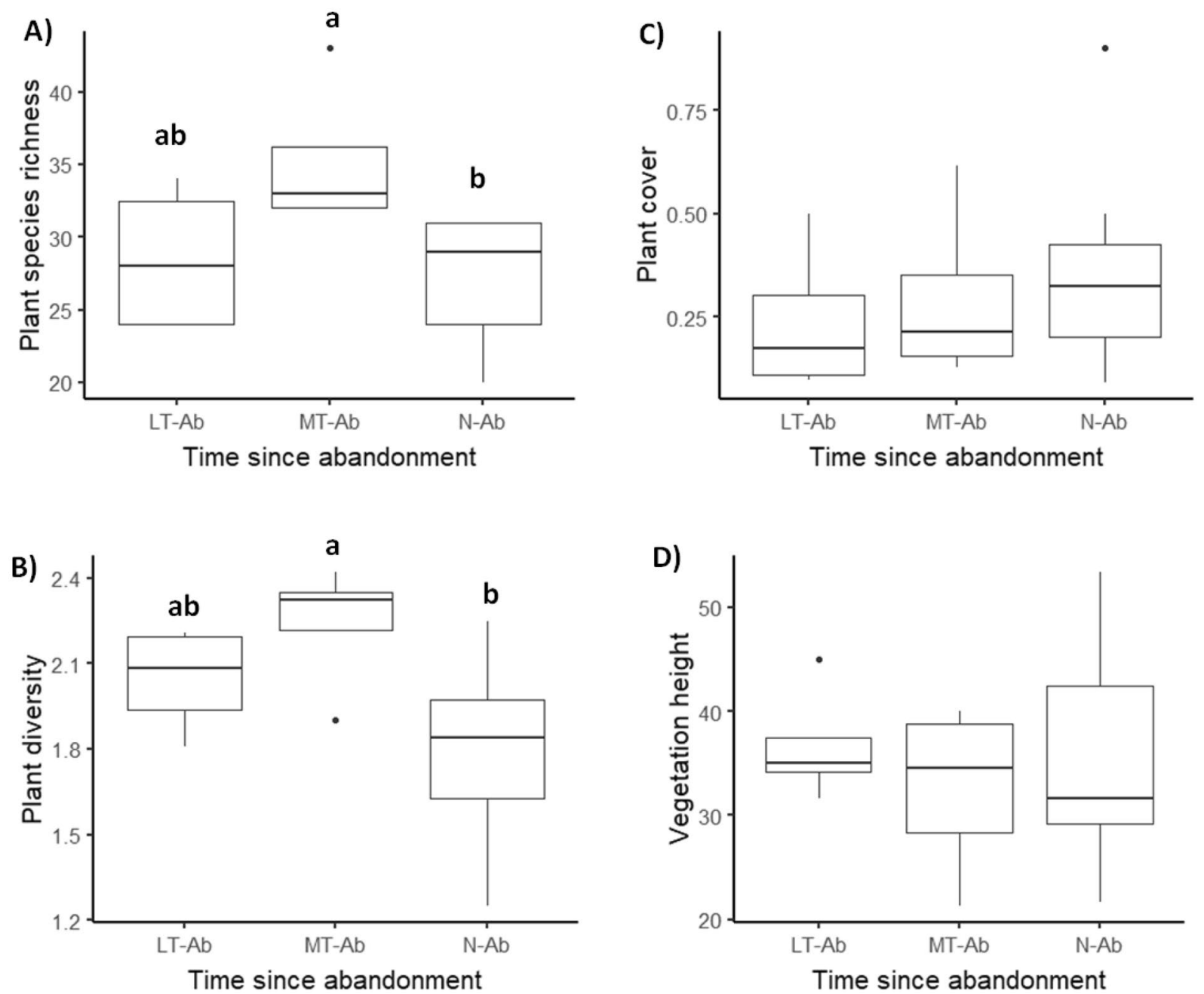

Fig. 4 Species richness (measured as observed species richness) (A), diversity (measured as Shannon index) $(\mathbf{B}),(\mathbf{C})$ cover of vascular plants, and vegetation height (D) in meadows of different years of abandonment, categorized as unabandoned ( $\mathrm{N}-\mathrm{Ab})$, mid-term aban-

mowing regime e.g. delayed cuts and maintaining uncut refuges, yielded higher butterfly densities $(+70 \%)$ and could prevent the negative impact of mowing on butterflies. As in these previous studies, it is likely that mowing contributed to reduced butterfly density in managed meadows in our study.

We found that butterfly community composition also showed major changes with time since abandonment, with a species turnover of $53 \%$ in the first years after abandonment and of $70 \%$ in the long term. Other studies have detected important community composition changes immediately after abandonment (Stefanescu et al. 2009) as well as an increasing tendency of community preference for closed habitats as time since abandonment proceeded (Herrando et al. 2016; Stefanescu et al. 2009).

We did not detect changes in butterfly species richness or diversity with time since abandonment, contrary to our

doned (MT-Ab) and long-term abandoned (LT-Ab). Different letters above the boxplots indicate significant differences between abandonment categories at $\mathrm{p}<0.05$ (Post-Hoc Tukey test)

expectations. In our study area, species richness response to environmental change seems to operate on a longer temporal scale than the 18 year period considered. Other studies on the effects of abandonment and grassland restoration with similar time spans ( 10 years) have been also unable to detect differences in species richness or diversity (Öckinger et al. 2006). Several authors remark that other aspects of biodiversity than species richness, particularly those based on species traits, could be more strongly affected by land-use pressures (Rotchés-Ribalta et al. 2018; Dainese et al. 2017; Valiente-Banuet et al. 2015).

Gagic et al. (2015) and Moretti et al. (2017) mention abundance-based traits composition of communities as a promising approach to advance current research on biodiversity and ecosystem functioning. Here we assessed the effects of abandonment on butterfly species traits, based on community indices for both habitat and trophic specialisation. 
A)

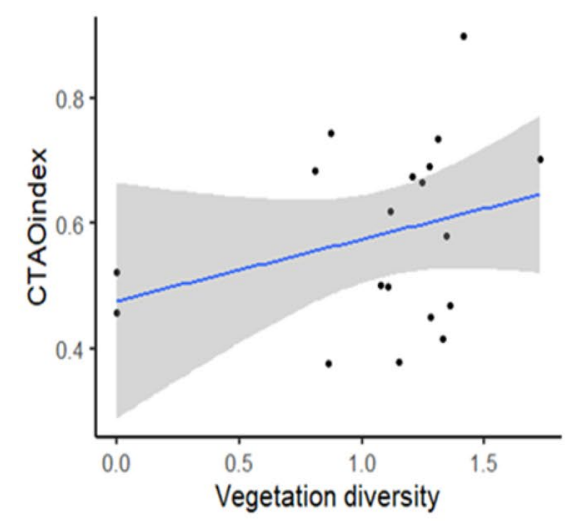

C)

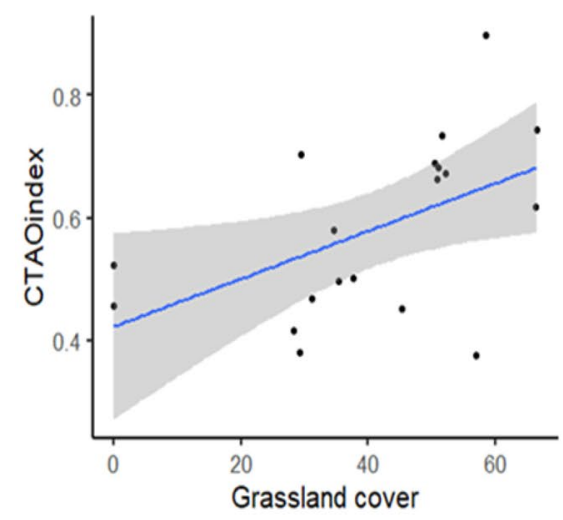

B)

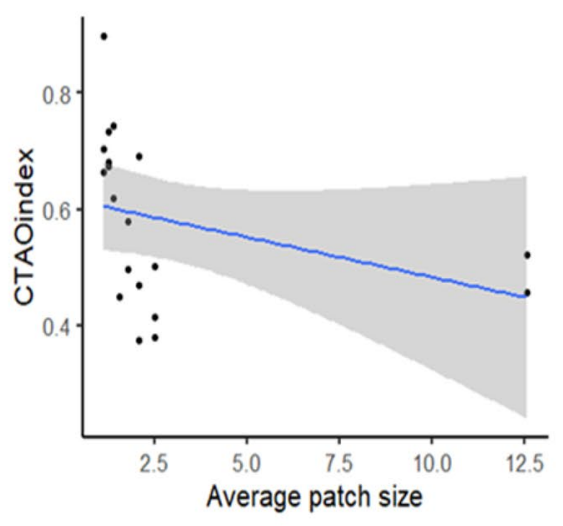

D)

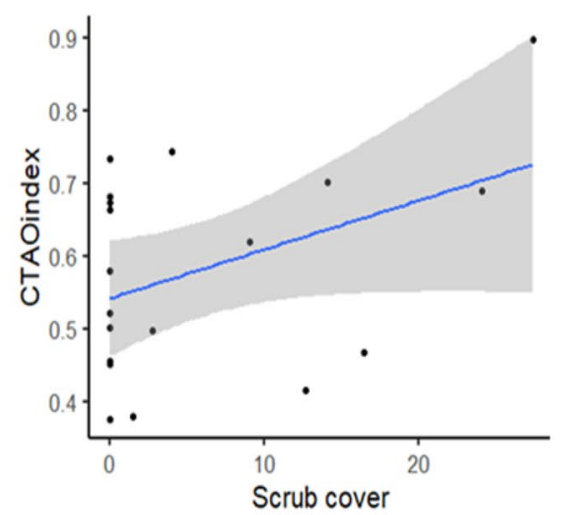

E)

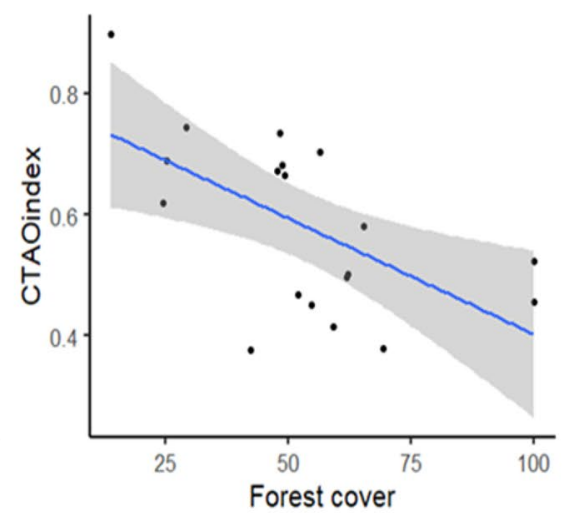

Fig. 5 Effects of landscape variables on butterfly community index of preferences for open/closed habitats (CTAO index). Landscape variables considered were: vegetation diversity (compositional hetero-

We detected a tendency for communities to lose grassland specialists in the short term but reorganising in the long term by gaining woodland specialist species. This resulted in a difference in community composition despite species richness remaining relatively stable. Although marginally nonsignificant $(\mathrm{p}=0.091)$, likely due to the limited number of meadows in our study, we found that community preference for closed habitats increased as time of abandonment proceeded. This makes sense as long-term abandoned meadows are generally located in parts of the landscape that have been abandoned first (not only meadows, but the whole mosaic) because they are located far from the village, or they have slopes over $30 \%$ that prevent mechanisation.

Landscape composition around the meadows strongly affected average community preference for open or closed habitats. The CTAO index for open/closed habitats decreased with forest cover (versus grassland or scrub cover) around the meadows but heterogeneous landscapes (in their composition - vegetation diversity, or in their configuration-average patch size) mitigated this effect. Our results show that geneity) (A), average patch size (configurational heterogeneity) (B), and cover of grassland (C), scrub (D) and forest (E) Grey shaded area shows the $95 \%$ confidence interval for the fitted line

landscape characteristics act as a strong filter of functional trait-diversity for butterfly communities within seminatural grasslands and dominate over local effects (Perović et al. 2015; Gámez-Virués et al. 2015; Seibold et al. 2019). This emphasises the importance of landscape scale management in conserving biodiversity (Gámez-Virués et al. 2015).

Our results support the idea that a highly heterogeneous cultural landscape mosaic around the meadows, produced by the combination of traditional farming practices, livestock grazing and forest management (Farina 2000), is moderating the negative effects of local land-use abandonment and influencing grassland species persistence, at both the local and landscape level. Those landscapes are also supporting a larger species pool, providing a diversity of patches with different disturbance dynamics and encouraging organisms to use different habitat patches with complementary resources (Tscharntke et al. 2012; Oliver et al. 2010).

A large species pool has allowed butterfly communities to reorganise, in a relatively short period of time (18 years) after perturbations ceased, into diverse and specialised 
assemblages. Contrary to our initial hypothesis, we did not find a higher number of species in managed grasslands. Rather than the substitution of specialists by generalists found in studies on agriculture intensified landscapes (Dainese et al. 2017), we found a negative trend of grassland specialists (e.g., Colias crocea, Polyommatus icarus, Boloria dia, Plebejus argus, Melitaea phoebe) versus a positive trend of woodland specialists (e.g,. Vanessa atalanta, Ochlodes sylvanus, Carterocephalus palaemon, Lycaena tityrus, Aphantopus hyperanthus), in line with other studies focusing on land abandonment (Stefanescu et al. 2011; Herrando et al. 2016; Ubach et al. 2020), suggesting species responses to environmental changes are context dependent (Melero et al. 2016).

Although we observed increases in woodland specialists, these species may also be at risk in the longer term because of a lack of woodland management. European woodland butterflies utilise sunny habitats within woodlands, such as sparse stands, bogs, stream sides, clearings, rides or edges. Managing woodlands for many threatened species consists of maintaining relatively low tree density and/or permanent or dynamically managed clearings (Settele et al. 2009). Abandoned hay meadows, embedded in forest patches, may be acting as forest clearings for woodland species. For example, Lopinga achine, a rare and endangered woodland species, in Picos de Europa area has taken advantage of hay meadow edges with forests, using them as a suitable habitat for breeding (Bergman 1999; Jubete et al. 2019). Population density of this species in Sweden peaked when canopy cover was around $70-85 \%$ and decreased at higher and lower canopy covers, with no populations being observed with canopy cover under 60\% (Bergman 2001). Therefore, more research is needed to determine if woodland butterfly species are also being affected by rural abandonment and vegetation encroachment.

\section{Conclusions}

In conclusion, butterfly communities associated with seminatural grassland in the Picos de Europa National Park are going through massive changes because of rural abandonment. The advance of forests over grasslands and the onward vegetation encroachment will homogenize landscapes, which may lead to a decline of open habitat specialist butterflies. Woodland specialist butterflies may also be at risk as they rely on woodland clearings, which are also disappearing because of vegetation encroachment and lack of woodland management. The Spanish Butterfly Monitoring Scheme, put in place in 2014, which includes the Picos de Europa National Park, will soon produce relevant data to analyse the wider impact of rural abandonment on the butterflies of Picos de Europa and Spain as a whole. In the meantime, we should ensure that communities have time to react to the diverse stressors imposed by global change. Facilitating survival to all kind of functional and taxonomic groups, implies promoting landscape heterogeneity and connectivity.

Supplementary Information The online version contains supplementary material available at https://doi.org/10.1007/s10841-021-00365-0.

Acknowledgements We thank you Martina Díaz, Iñaki Díez, Susana Marquínez and Beatriz Sobrecueva for helping with field surveys. We also thank you Dr. Herminio Nava for revising the plant identification and José Enrique Díez for providing information about meadow management. The Picos de Europa National Park provided financial support as well as the relevant permit to carry out the research in the protected area.

Author contributions All authors contributed to the study conception and design. Data collection was performed by AM and data analysis was performed by AM with input from RM and AW. The first draft of the manuscript was written by AM and all authors commented on previous versions of the manuscript. All authors read and approved the final manuscript.

Funding The Picos de Europa National Park authorities supported this research.

Data availability All data relevant to this research is provided in the supplementary information.

Code availability Not applicable.

\section{Declarations}

Conflict of interest The authors have no conflicts of interest to declare that are relevant to the content of this article.

Ethical approval Not applicable.

Informed consent Not applicable.

Consent for publication Not applicable.

Open Access This article is licensed under a Creative Commons Attribution 4.0 International License, which permits use, sharing, adaptation, distribution and reproduction in any medium or format, as long as you give appropriate credit to the original author(s) and the source, provide a link to the Creative Commons licence, and indicate if changes were made. The images or other third party material in this article are included in the article's Creative Commons licence, unless indicated otherwise in a credit line to the material. If material is not included in the article's Creative Commons licence and your intended use is not permitted by statutory regulation or exceeds the permitted use, you will need to obtain permission directly from the copyright holder. To view a copy of this licence, visit http://creativecommons.org/licenses/by/4.0/.

\section{References}

Alonso Felpete JI, González Robinson S, Fernández Rodríguez A, Sanzo Rodríguez, Mora Cabello de Alba A, Bueno Sánchez A, 
Díaz González TE (2011) Catálogo florístico del Parque Nacional de los Picos de Europa. Documentos del Jardín Botánico Atlántico, no. 8. Ayuntamiento de Gijón

Alonso JI et al (2013) Mapa de vegetación 1:10.000 del Parque Nacional Picos de Europa. Memoria de análisis global de la vegetación del Parque Nacional Picos de Europa. Organismo Autónomo Parques Nacionales

Balmer O, Erhardt A (2000) Consequences of succession on extensively grazed grasslands for central European butterfly communities: rethinking conservation practices. Conserv Biol 14:746-757. https://doi.org/10.1046/j.1523-1739.2000.98612.x

Bates D, Maechler M, Bolker B, Walker S (2015) Fitting linear mixedeffects models using lme4. J Stat Softw 67(1):1-48. https://doi. org/10.18637/jss.v067.i01

Bergman KO (1999) Habitat utilisation by Lopinga achine (Nymphalidae: Satyrinae) larvae and ovipositing females: implications for conservation. Biol Conserv 88:69-74

Bergman KO (2001) Population dynamics and the importance of habitat management for conservation of the butterfly Lopinga achine. J Appl Ecol 38:1303-1313

Brondizio ES, Settele J, Ngo HT (eds) (2019) Global assessment report on biodiversity and ecosystem services of the Intergovernmental Science-Policy Platform on Biodiversity and Ecosystem Services. IPBES secretariat, Bonn, Germany

Bruppacher L, Pellet J, Arlettaz R, Humbert J (2016) Simple modifications of mowing regime promote butterflies in extensively managed meadows: evidence from field-scale experiments. Biol Conserv 196:196-202. https://doi.org/10.1016/j.biocon.2016.02.018

Colom P, Traveset A, Stefanescu C (2021) Long-term effects of abandonment and restoration of Mediterranean meadows on butterfly-plant interactions. J Insect Conserv. https://doi.org/10.1007/ s10841-021-00307-w

Dainese M, Isaac NJB, Powney G, Bommarco R, Öckinger E, Kuussaari M, Pöyry J, Benton TG, Gabriel D, Hodgson JA, Kunin WE, Lindborg R, Sait SM, Marini L (2017) Landscape simplification weakens the association between terrestrial producer and consumer diversity in Europe. Glob Change Biol 23:3040-3051

Dantas de Miranda M, Pereira HM, Corley MFV, Merckx T (2019) Beta diversity patterns reveal positive effects of farmland abandonment on moth communities. Sci Rep 9:1549. https://doi.org/ 10.1038/s41598-018-38200-3

De Cáceres M, Legendre P (2009) Associations between species and groups of sites: indices and statistical inference. http://sites. google.com/site/miqueldecaceres/

De Cáceres M (2020) How to use the indicspecies package. https:// cran.r-project.org/wweb/packages/indicspecies/vignettes/indic speciesTutorial.pdf Accessed 29 Jan 2021

Devictor V, van Swaay C, Brereton T, Brotons L, Chamberlain D, Heliölä J, Herrando S, Julliard R, Kuussaari M, Lindström A, Reif J, Roy B, Schweiger O, Settele J, Stefanescu C, van Strien A, van Turnhout C, Vermouzek Z, Wallis De Vries M, Wynhoff I, Jiguet F (2012) Differences in the climatic debts of birds and butterflies at a continental scale. Nat Clim Chang 2:121. https:// doi.org/10.1038/nclimate1347

Dover JW, Rescia A, Fungariño S, Fairburn J, Carey P, Lunt P, Dennis RLH, Dover CJ (2010) Can hay harvesting detrimentally affect adult butterfly abundance? J Insect Conserv 14:413-418. https:// doi.org/10.1007/s10841-010-9267-5

Dufrêne M, Legendre P (1997) Species assemblages and indicator species: the need for a flexible asymmetrical approach. Ecol Monogr 67(3):345-366

Farina A (2000) The cultural landscape as a model for the integration of ecology and economics. Bioscience 50(4):313-320. https://doi. org/10.1641/0006-3568(2000)050[0313:TCLAAAM]2.3.CO;2
Gagic V, Bartomeus I, Jonsson T, Taylor A, Winqvist C, Fischer C, Slade EM, Steffan-Dewenter I, Emmerson M, Potts SG, Tscharntke T, Weisser W, Bommarco R (2015) Functional identity and diversity of animals predict ecosystem functioning better than species-based indices. Proc R Soc B 282:20142620

Gámez-Virués S, Perović DJ, Gossner MM, Börschig C, Blüthgen N, de Jong H, Simons NK, Klein A, Krauss J, Maier G, Scherber C, Steckel J, Rothenwöhrer C, Steffan-Dewenter I, Weiner CN, Weisser W, Werner M, Tscharntke T, Westphal C (2015) Landscape simplification filters species traits and drives biotic homogenization. Nat Commun. https://doi.org/10.1038/ncomms9568

García P, García L, González V (2018) Diagnóstico de la situación de prados de siega en el suroeste europeo: análisis diacrónico en el Parque Nacional de los Picos de Europa. Naturalia Cantabricae 6(1):1-21

García-Barros E, Munguira ML, Stefanescu C, Vives-Moreno A (2013) Lepidoptera, Papilionoidea. In: Ramos MA et al (eds) Fauna Ibérica, vol. 37. Museo Nacional de Ciencias Naturales, CSIC, Madrid

García-Llamas P, Geijzendorffer IR, García-Nieto AP, Calvo L, SuárezSeoane S, Cramer W (2019) Impact of land cover change on ecosystem service supply in mountain systems: a case study in the Cantabrian Mountains (NW of Spain). Reg Environ Change 19:529-542. https://doi.org/10.1007/s10113-018-1419-2

Greenpeace Spain (2020) https://es.greenpeace.org/es/sala-de-prensa/ informes/proteger-el-medio-rural-es-protegernos-del-fuegohacia-paisajes-y-poblacion-resilientes-frente-a-la-crisis-clima tica/ Accessed 22 Feb 2021

Herrando S, Brotons L, Anton M, Páramo F, Villero D, Titeux N, Quesada J, Stefanescu C (2016) Assessing impacts of land abandonment on Mediterranean biodiversity using indicators based on bird and butterfly monitoring data. Environ Conserv. https://doi.org/ $10.1017 / \mathrm{S} 0376892915000260$

Humbert J, Ghazoul J, Richner N, Walter T (2012) Uncut grass refuges mitigate the impact of mechanical meadow harvesting on orthopterans. Biol Conserv 152:96-101

Humbert J, Ghazoul J, Sauter GJ, Walter T (2010) Impact of different meadow mowing techniques on field invertebrates. J Appl Entomol 134:592-599

Janišová M, Michalcová D, Bacaro G, Ghisla A (2014) Landscape effects on diversity of semi-natural grasslands. Agric Ecosyst Environ 182:47-58

Johst K, Drechsler M, Thomas J, Settele J (2006) Influence of mowing on the persistence of two endangered large blue butterfly species. J Appl Ecol 43:333-342

Jubete F, Barea JM, Escobés R, Galante E, Gómez-Calmaestra R, Manceñido DC, Monasterio Y, Mora A, Munguira ML, Stefanescu C, Tinaut A (2019) Bases técnicas para la conservación de los lepidópteros amenazados en España. Asociación de Naturalistas Palentinos

Julliard R, Clavel J, Devictor V, Jiguet F, Couvet D (2006) Spatial segregation of specialists and generalists in bird communities. Ecol Lett 9:1237-1244

Konvicka M, Benes J, Cizek O, Kopecek F, Konvicka O, Vitaz L (2008) How too much care kills species: grassland reserves, agri-environmental schemes and extinction of Colias myrmidone (Lepidoptera: Pieridae) from its former stronghold. J Insect Conserv 12:519-525

Krauss J, Steffan-Dewenter I, Tscharntke T (2003) How does landscape context contribute to effects of habitat fragmentation on diversity and population density? J Biogeogr 30:889-900

Marini L, Fontana P, Battisti A, Gaston KJ (2009) Agricultural management, vegetation traits and landscape drive orthopteran and butterfly diversity in a grassland-forest mosaic: a multi-scale approach. Insect Conserv Divers 2:213-220 
McKenney ML, Lockwood JL (1999) Biotic homogeneization: a few winners replacing many losers in the next mass extinction. Trends Ecol Evol 14:450-453

Melero Y, Stefanescu C, Pino J (2016) General declines in Mediterranean butterflies over the last two decades are modulated by species traits. Biol Conserv 201:336-342

Moretti M, Dias ATC, Bello F, Altermatt F, Chown SL, Azcárate FM, Bell JR, Fournier B, Hedde M, Hortal J, Ibanez S, Öckinger E, Sousa JP, Ellers J, Berg MP (2017) Handbook of protocols for standardized measurement of terrestrial invertebrate functional traits. Funct Ecol 31:558-567

Öckinger E, Schweiger O, Crist TO, Debinski DM, Krauss J, Kuussaari M, Petersen JD, Pöyry J, Settele J, Summerville KS, Bommarco R (2010) Life-history traits predict species responses to habitat area and isolation: a cross-continental synthesis. Ecol Lett 13:969-979

Öckinger E, Bergman KO, Franzén M, Kadlec T, Krauss J, Kuussaari M, Pöyry J, Smith HG, Steffan-Dewenter I, Bommarco R (2012) The landscape matrix modifies the effect of habitat fragmentation in grassland butterflies. Landsc Ecol 27:121-131

Öckinger E, Smith G, Eriksson K, Henrik A (2006) Effects of grassland abandonment, restoration and management on butterflies and vascular plants. Biol Conserv 133:291-300

Oksanen JF, Blanchet G, Friendly M, Kindt R, Legendre P, McGlinn D, Minchin PR, O'Hara RB, Simpson GL, Solymos P, Henry M, Stevens H, Szoecs E, Wagner H (2019) Vegan: community ecology package. R package version 2.5-6. https://CRAN.R-project. org/package $=$ vegan

Oliver T, Roy DB, Hill JK, Brereton T, Thomas CD (2010) Heterogeneous landscapes promote population stability. Ecol Lett. https://doi. org/10.1111/j.1461-0248.2010.01441.x

Perović D, Gámez-Virués S, Börschig C, Klein A, Krauss J, Steckel J, Rothenwöhrer C, Erasmi S, Tscharntke T, Westphal C (2015) Configurational landscape heterogeneity shapes functional community composition of grassland butterflies. J Appl Ecol 52:505-513

Pollard E, Yates TJ (1993) Monitoring butterflies for ecology and conservation. Chapman \& Hall, London

Poschlod P, Bakket JP, Kahmen S (2005) Changing land use and its impact on biodiversity. Basic Appl Ecol 6:93-98

Pöyry J, Paukkunen J, Heliölä J, Kuussaari M (2009) Relative contributions of local and regional factors to species richness and total density of butterflies and moths in semi-natural grasslands. Oecologia 160:577-587

Rivas-Martínez S, Díaz TE, Prieto JAF, Loidi J, Penas A (1984) La vegetación de la alta montaña cantábrica. Los Picos de Europa. Ed. Leonesas

Romo H, Munguira ML, García-Barros E (2007) Area selection for the conservation of butterflies in the Iberian Peninsula and Balearic Islands. Anim Biodivers Conserv 30(1):7-27

Rotchés-Ribalta R, Winsa M, Roberts SPM, Öckinger E (2018) Associations between plant and pollinator communities under grassland restoration respond mainly to landscape connectivity. J Appl Ecol 55(6):2822-2833. https://doi.org/10.1111/1365-2664.13232

R Studio Team (2019) RStudio: integrated development for R. RStudio, Inc., Boston, MA. https://www.rstudio.com/

Seibold S, Gossner MM, Simons NK, Blüthgen N, Müller J, Ambarli D, Ammer C, Bauhus J, Fischer M, Habel JC, Linsenmair KE, Nauss T, Penone C, Prati D, Schall P, Schulze E, Vogt J, Wöllauer S, Weisser W (2019) Arthropod decline in grasslands and forests is associated with landscape-level drivers. Nature 574:671-674. https://doi.org/10.1038/s41586-019-1684-3

Settele J, Dover J, Dolek M, Konvicka M (2009) Butterflies of European ecosystems: impact of land use and options for conservation management. In: Settele J, Shreeve T, Konvicka M, van Dyck $\mathrm{H}$ (eds) Ecology of butterflies in Europe. Cambridge University Press, Cambridge, pp 353-370
Skórka P, Settele J, Woyciechowski M (2007) Effect of management cessation on grassland butterflies in southern Poland. Agric Ecosyst Environ 121:319-324

Slancarova J, Bartonova A, Zapletal M, Kotilinek M, Fric ZF, Micevski N, Vasiliki K, Konvicka M (2016) Life history traits reflect changes in Mediterranean butterfly communities due to forest encroachment. PLoS ONE. https://doi.org/10.1371/journal.pone. 0152026

Stefanescu C, Carnicer J, Peñuelas J (2010) Determinants of species richness in generalist and specialist Mediterranean butterflies: the negative synergistic forces of climate and habitat change. Ecography 34:353-363

Stefanescu C, Peñuelas J, Filella I (2009) Rapid changes in butterfly communities following the abandonment of grasslands: a case study. Insect Conserv Divers 2:261-269

Stefanescu C, Torre I, Jubany J, Páramo F (2011) Recent trends in butterfly populations from north-east Spain and Andorra in the light of habitat and climate change. J Insect Conserv 15:83-93

Tscharntke T, Bommarco R, Clough Y, Cris TO, Kleijn D, Rand TA, Tylianakis JM, van Nouhuys S, Vidal S (2007) Conservation biological control and enemy diversity on a landscape scale. Biol Control 43(3):294-309

Tscharntke T, Tylianakis JM, Rand TA, Didham RK, Fahrig L, Batáry P, Bengtsson J, Clough Y, Crist TO, Dormann CF, Ewers RM, Fründ J, Holt RD, Holzschuh A, Klein AM, Kleijn D, Kremen C, Landis DA, Laurance W, Lindenmayer D, Scherber C, Sodhi N, Steffan-Dewenter I, Thies C, Putten WH, van der Westphal C (2012) Landscape moderation of biodiversity patterns and processes: eight hypothesis. Biol Rev 87:661-685

Ubach A, Páramo F, Gutiérrez C, Stefanescu C (2020) Vegetation encroachment drives changes in the composition of butterfly assemblages and species loss in Mediterranean ecosystems. Insect Conserv Divers. https://doi.org/10.1111/icad.12397

Uchida K, Ushimaru A (2014) Biodiversity declines due to abandonment and intensification of agricultural lands: patterns and mechanisms. Ecol Monogr 84:637-658. https://doi.org/10.1890/ 13-2170.1

Uchida K, Takahashi S, Shinohara T, Ushimaru A (2016) Threatened herbivorous insects maintained by long-term traditional management practices in semi-natural grasslands. Agric Ecosyst Environ 221:156-162

Valiente-Banuet A, Aizen MA, Alcántara JM, Arroyo J, Cocucci A, Galetti M, García MB, García D, Gómez JM, Jordano P, Medel R, Navarro L, Obeso JR, Oviedo R, Ramírez N, Rey PJ, Traveset A, Verdú M, Zamora R (2015) Beyond species loss: the extinction of ecological interactions in a changing world. Funct Ecol 29:299-307

van Halder I, Barbaro L, Jactel H (2011) Conserving butterflies in fragmented plantation forests: are edge and interior habitats equally important? J Insect Conserv 15:91-601

van Swaay CAM, Warren MS (2006) Prime butterfly areas of Europe: an initial selection of priority sites for conservation. J Insect Conserv 10:5-11

van Swaay CAM et al (2016) The European Butterfly Indicator for Grassland species 1990-2015. Report VS2016.019, De Vlinderstichting, Wageningen

Publisher's Note Springer Nature remains neutral with regard to jurisdictional claims in published maps and institutional affiliations. 